\title{
The Disheartening Speech by the President of Bulgaria's Supreme Court Which Nobody in Brussels Noticed
}

VB verfassungsblog.de/the-disheartening-speech-by-the-president-of-bulgarias-supreme-court-which-nobody-in-brusselsnoticed/

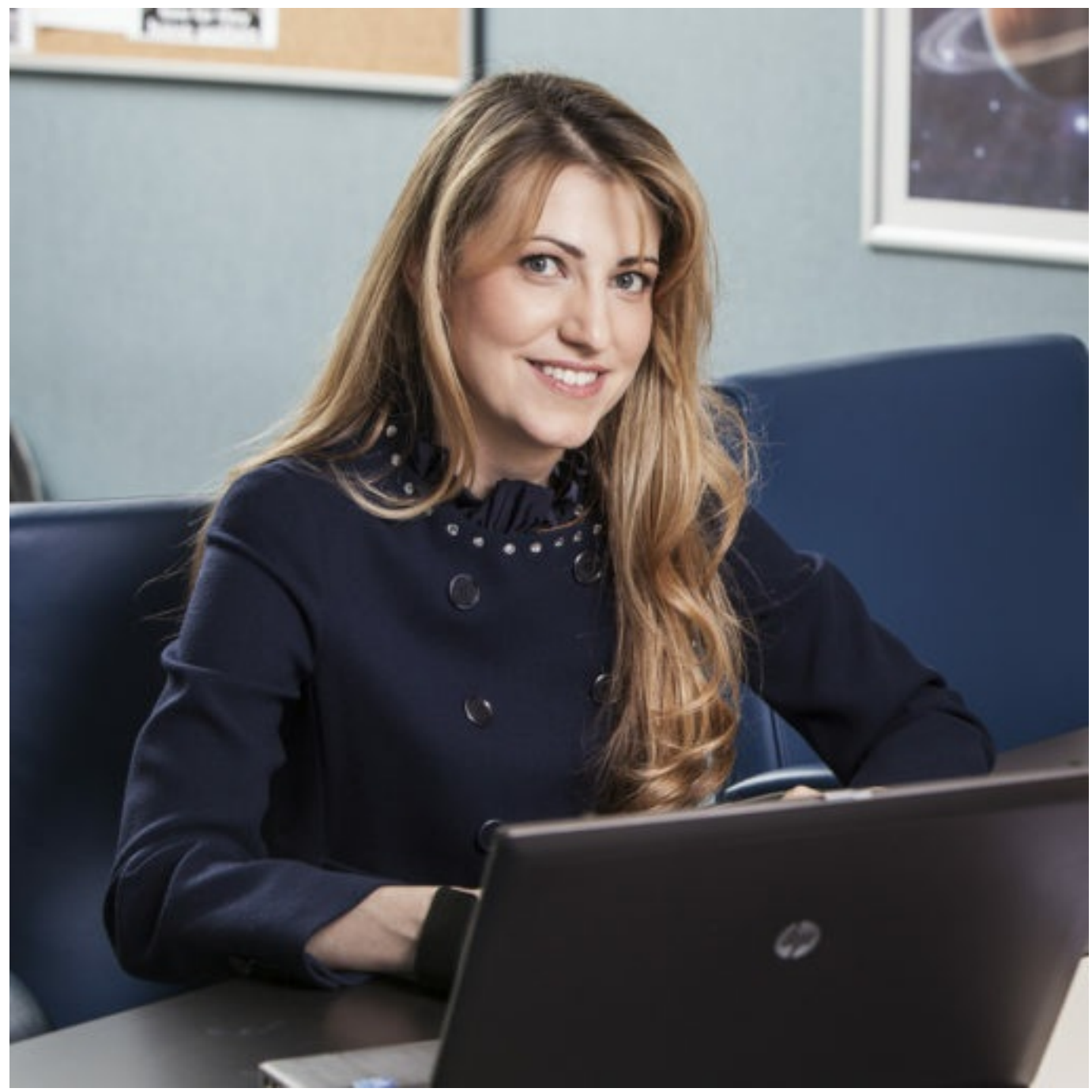

A month ago, the President of Bulgaria's Supreme Court of Cassation Lozan Panov gave a disheartening speech, which seems to have gone unnoticed in Brussels. "I wish I could tell you that...the copulation between the judiciary and the executive branch has been limited. Instead, I must tell you that the attacks against the judiciary members who refuse to copulate with the executive have become crueler," argued Panov. He pointed out a series of failures to serve justice, which had taken place because of dealings behind the curtain, and complained against the pressures to which he and his family had been subjected because he refused to comply with what he referred to as the "evil." "Woe betide anyone who opposes the untouchable status of [Bulgaria's] Chief Prosecutor," lamented the highest-ranking judge in the country.

While many foreign commentators focus on the endangered democratic values in Poland and Hungary, the situation in Bulgaria is equally deplorable. If the President of the Supreme Court contends that there is no separation of powers and that his family is facing abuse 
because he turns down orders by the executive, then surely ordinary citizens, especially critics of the government, have no means to protect themselves from the rage of those who have captured the Bulgarian State.

It is worth mentioning, of course, that the speech made by the President of Bulgaria's Supreme Court of Cassation is not the first of its kind. At the 135th anniversary of Bulgaria's Supreme Court in 2015, he asked his colleagues to be brave: "We need to fight with all strength, we have to ensure that the court has the degree of independence which is necessary to promote the rule of law...Say no to fear!" Sadly, three years later, the eyes of fear are colder. Bulgaria is torn by scandals of corruption, political persecutions, and lynching of judges who refuse to succumb to pressure to satisfy the whims of Bulgaria's Prosecutor's Office.

Indeed, Bulgaria's Prosecutor's Office, which has not been reformed since communist times, has been weaponized by the corrupt status quo. It has a vertical, "Stalinist" structure where all decisions depend on one person - the Chief Prosecutor who is appointed for a period of seven years. At the same time, he does not bear any responsibility for his actions or omissions because of his untouchable status under Bulgaria's constitution. This functional particularity creates opportunities for political abuse, which explains why Bulgaria's Prosecution currently "benefits" from $\underline{6 \%}$ public confidence.

For years, the Venice Commission and the Council of Europe have raised concern about the status of Bulgaria's Prosecutor's Office and have called for reforms to no avail. In 2016, the President of the Venice Commission said: "The Soviet model of the prosecution must be decisively turned down. It turns it into a source of corruption and blackmail and creates opportunities for its use for political aims." In March 2018, the Committee of Ministers of the Council of Europe invited Bulgaria to "provide information on the concrete reforms envisaged to ensure the independence, in law and in practice, of an investigation against the Chief Prosecutor."

Nothing has been done to conform with these recommendations. What is worse is that the excessive powers of the Chief Prosecutor have spilled over to the Supreme Judicial Council, which is the body responsible for the appointment and promotion of magistrates as well as for monitoring their ethical values. The representatives of the Prosecutor's and the Criminal Investigators' Office in this Council are directly subordinate to the Chief Prosecutor. Thus, in practice, they close their eyes to all ethical violations and promote only the colleagues endorsed by him. The election of a Deputy Chief Prosecutor, nominated by the Chief Prosecutor himself, earlier this month is particularly revealing - none of the members of the Supreme Judicial Council asked any questions and the vote was unanimous.

\section{False comfort}

Sadly, these persistent problems are overlooked by EU institutions. One may put forward various reasons which shed light on their silence. Bulgaria, along with Romania, is subjected to the Cooperation and Verification Mechanism, which provides the false comfort that there is a procedure ensuring compliance with EU values. Indeed, Bulgaria's 
democracy has deteriorated since the country's entry into the EU in 2007. Bulgaria is currently ranked as the most corrupt EU Member State by Transparency International and it was recently downgraded to a semi-consolidated democracy by Freedom House.

Moreover, the country just finished its six-month Presidency of the Council of the EU. It is a public secret that EU institutions are overly diplomatic with presiding Member States to prevent scandals. In fact, President Juncker even said that Bulgaria has the capacity to lead in the area of rule of law, which is quite ironic given the current deplorable state of affairs. Most of all, nonetheless, as pointed out by Tom Junes in an article for Balkan Insight, Bulgaria's policies "might resemble those of Hungary or Poland," but Bulgaria does not rock "the EU boat."

In other words, the price of neglecting the heartbreaking speech of the highest-ranking Bulgarian judge is rather high - dual standards on the Treaty on European Union.

Bulgaria's persistent disrespect for EU values is ignored merely because Bulgaria's corrupt government does not challenge Brussels' authority. This, in turn, is a dangerous precedent as EU nationals are supposed to have the same rights: Bulgarians should not be treated as second-class citizens. Furthermore, Brussels fails courageous judges like Lozan Panov who literally risk their lives - he was already hit by a car in mysterious circumstances - at a critical point in Bulgaria's struggle for the rule of law. Without the active support of EU institutions, however, Bulgaria's civil society cannot save its fragile democracy.

\section{LICENSED UNDER CC BY NC ND}

SUGGESTED CITATION Vassileva, Radosveta: The Disheartening Speech by the President of Bulgaria's Supreme Court Which Nobody in Brussels Noticed, VerfBlog, 2018/7/11, https://verfassungsblog.de/the-disheartening-speech-by-the-president-ofbulgarias-supreme-court-which-nobody-in-brussels-noticed/, DOI:

https://doi.org/10.17176/20180711-152643-0. 